\title{
The Ichthyofauna of Aghstev and Debed River Basins (North Armenia) and the Impact of Separate Factors on its Transformation
}

Pipoyan $\mathrm{S}^{1 *}$ and Arakelyan $\mathrm{A}^{2}$

${ }^{1}$ Doctor of biological sciences, professor, Chair of Biology and its Teaching Methods, Armenian State Pedagogical University after Kh. Abovyan, Armenia

${ }^{2} \mathrm{Ph}$. D. student, Zoology, NAS RA Scientific Center of Zoology and Hydroecology, Institute of Zoology, Armenia

${ }^{*}$ Corresponding author: Samvel Pipoyan, Doctor of biological sciences, professor, Chair of Biology and its Teaching Methods, Armenian State Pedagogical University after Kh. Abovyan, 17 Tigran Mets ave., 0010, Yerevan, Armenia, Tel:+374 -91-49- 96- 90; Email: s.pipoyan@gmail.com

\section{Abstract}

It is well known that Aghstev and Debed river basins (North Armenia) are not famous for their fish diversity. According to M. Dadikyan only 7 main species had inhabited in the above mentioned river basins until 70th of 20th century. Later, the studies conducted from 1990 to 2005 indicated that the fish diversity has completely changed: reaching up to 13 . As a result the recent studies have shown that the quantity of fish species of rivers belonging to Aghstev and Debed river basins has increased up to 19. Since 1970 more than double growth of fish species diversity is conditioned by the fish species released in the rivers by amateur fisherman or imported fishes randomly falling into wild freshwaters from private small farms. It's worth mentioning that the quantity of local habitat fish species mainly valuable fish species (Salmo trutta, Salmo caspius, Capoeta capoeta, etc.) has reduced the reasons of which are banned poaching, the exploitation of small hydro power plant (SHPP), pollution of river water with household waste water and the usage for agricultural purposes.

Keywords: Ichthyofauna; Fish diversity; Aghstev and Debed river basins; SHPP

\section{Introduction}

The area of the Republic of Armenia is 29.8 thousand square kilometers and is located in the southern part of
Transcaucasia, occupying a small northeastern part of the vast Armenian upland. From north and east Armenia is framed by the ridges of the Lesser Caucasus. The area of Armenia belongs to East Transcaucasian District 


\section{International Journal of Oceanography \& Aquaculture}

belonging to Caucasian Province. The main rivers in the region include Kura and Aras with their tributaries then Vilyashchay, Lenkoran' and Safid Rud [1]. Armenian freshwaters belong to 2 large river basins, i.e Kura and Aras. The basin of river Aras occupies 22790 square kilometers or $76.5 \% 8700$ kilometers in the territory of Armenia. Kura basin occupies 7010 square kilometers or $23.5 \%$ of river net, 4400 kilometers. So, river network density of Aras basin forms 0.38 kilometers/square kilometers, Kura forms 0.63 kilometers/square kilometers. The big rate of river network density of Kura river basin is conditioned by both the high quantity of precipitations and low filtration properties that reduce the flow [2-4].

Rivers of northern and north-eastern Armenia belong to the basin of river Kura (Figure 1). The largest of them are rivers Debed and Aghstev. They rise at the height of 2500 above the level and flow into river Kura outside the territory of Armenia. Debed (Figure 2) is the right tributary of Khram River. It is formed by the mix of Dzoraget and Pambak Rivers. The length of river Pambak is $178 \mathrm{~km}$, hydrologic basin is 4080 square kilometers. The length of Debed River in Armenia is $152 \mathrm{~km}$, and the rest is in the territory of Georgia. Flows of Debed and its tributaries are sharply seasonal, maximum spring flows exceed minimum winter flows 100 times. The large tributaries of Debed are Dzoraget, Pambak, Tashir, Marts and Shnogh. Dzoraget rises in the southern slopes of Javakhq Ridge, at the height of 2320 meters. The length is 67 kilometers; the hydrologic basin is 1460 square kilometers. The large tributary of this river is Tashir which rises at the height of 1800 meters; it has 54 kilometers length and 470 kilometers hydrologic basin. Pambak rises at the height of 2100 meters; it has 92 kilometers length and 1370 square kilometers hydrologic basin. Mart rises at the height of 1980 meters. The length is 29 kilometers, and the hydrologic basin is 252 square kilometers. The length of Shnogh is 20 kilometers; the hydrologic basin is 114 square kilometers.

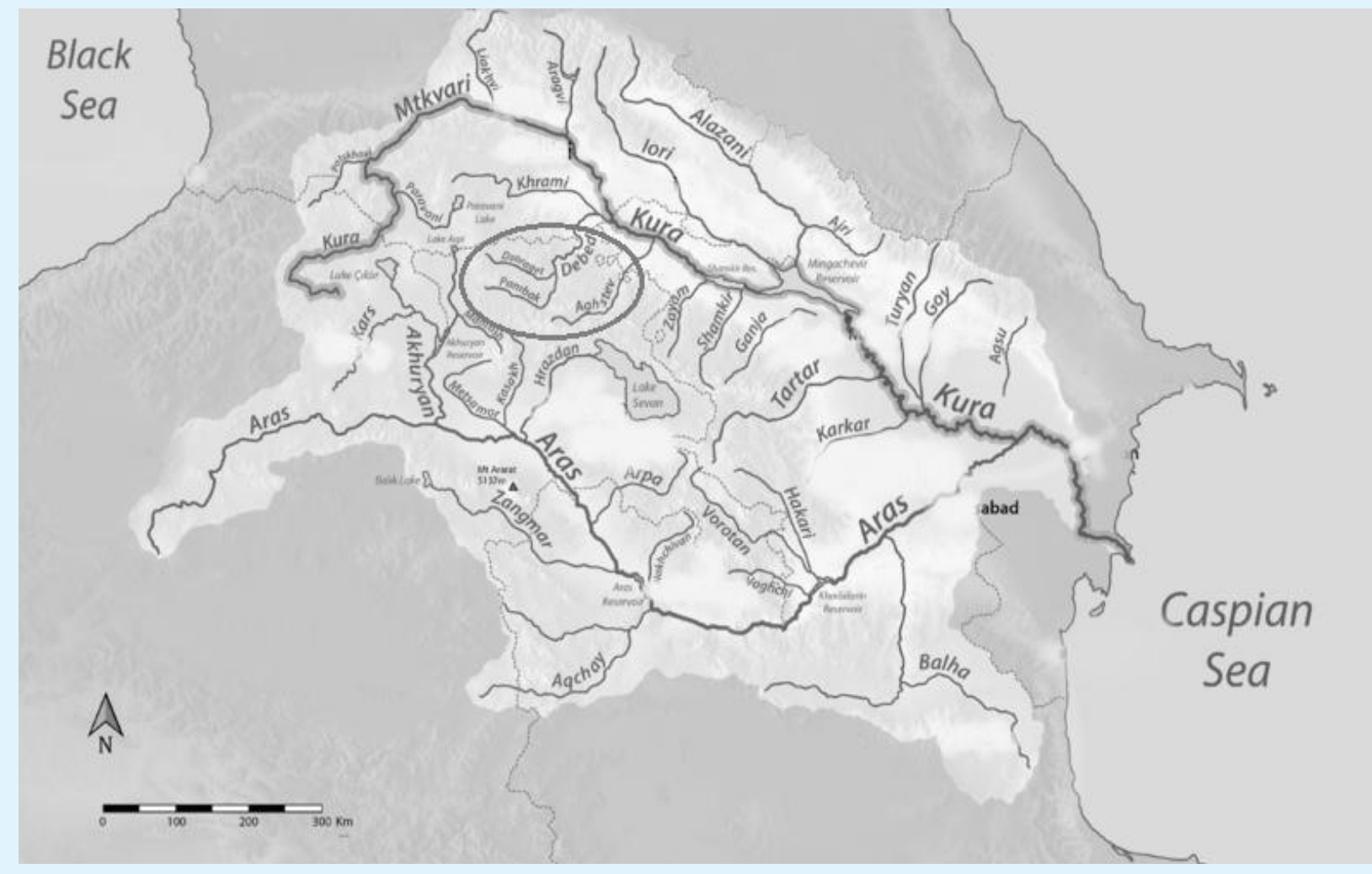

Figure 1: Rivers belonging to Kura River. The basin of the rivers studied by us is circled. /the map is taken from en.wikipedia.org/wiki/Kura_(Caspian_Sea) website. 


\section{International Journal of Oceanography \& Aquaculture}

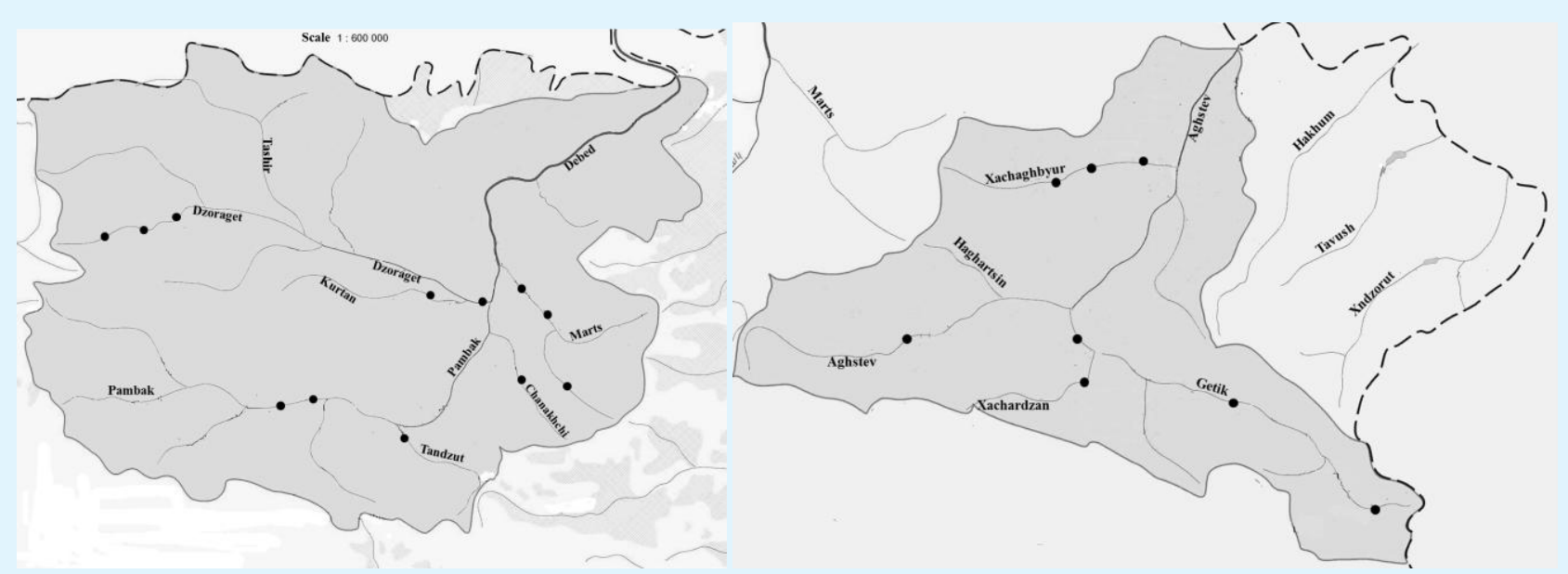

Figure 2: Basin of Debed and Aghstev rivers. Separate SHPPs located on rivers are black spotted (maps are taken from http://armmonitoring.am/ website).

River Aghstev (Figure 2) is the right tributary of Kura. It rises in Pambak Ridge at the height of 2985 meters. The length is 133 kilometers, 81 kilometers of which flows in the territory of Armenia and the 52 kilometers in Azerbaijan. The drainage basin is 2589 square kilometers, from which 1730 square kilometers is in Armenia. River Aghstev with its tributaries (rr. Ddzogas, Voskepar) has pluvial regime of feeding which is characterized by sharply expressed seasonal flow from which the maximum belongs to the period May-June. The large tributaries are Bldan, Haghartsin, Sarnajur, Voskepar and Getik. Bldan rises at the height 2800 meters. The length is 15 kilometers; hydrologic basin is 72 square kilometers. Getik rises at the height of 2620 meters. The length is 56 kilometers and the hydrologic basin is 586 square kilometers. Haghartsin rises at the height of 2200 meters, the length is 10 kilometers and the hydrologic basin is 38 square kilometers. Voskepar rises at the height of 1975 meters, the length is 59 kilometers and the hydrologic basin is 510 square kilometers. Sarnajur rises at the height of 1975 meters, the length is 29 kilometers and the hydrologic basin is 205 square kilometers [4-6].

The fish faunas of drainages from Kura to Safid are very close. Historically, 73 native species and subspecies /ESU/OSU belonging to 44 genera of 14 families have been reported in the East Transcaucasian District. Twenty-seven are endemic: Acanthalburnus microlepis (De Filippi, 1863), Alburnoides eichwaldii (De Filippi, 1863), Alburnoides cf. eichwaldii (from Safid Rud), Alburnus filippii Kessler, 1877, Leuciscus aspius (L., 1758), Barbus goktschaicus Kessler, 1877, Blicca bjoerkna transcaucasica Berg, 1916, Capoeta sevangi De Filippi,
1865, Chondrostoma cyri Kessler, 1877, Cobitis cf. satunini, Leucalburnus satunini (Berg, 1910), Paracobitis cyri (Berg, 1910), P. malapterura (Valenciennes, 1846), Ponticola cyrius (Kessler, 1874), Pseudophoxinus atropatenus (Derzhavin, 1937), P. sojuchbulagi (Abdurakhmanov, 1950), Rhodeus cf. amarus, Romanogobio macropterus (Kamensky, 1901), Rutilus rutilus (L., 1758), Salmo ischchan Kessler, 1877, S. aestivalis Fortunatov, 1926, S. danilewskii Gul'elmi, 1888, S. gegarkuni Kessler, 1877, Oxynoemacheilus bergi (Gratzianow, 1907), O. bergianus (Derzhavin,1934), $O$. brandtii (Kessler, 1877), $O$. lenkoranensis (Abdurakhamanov, 1962) [1]. The East Transcaucasian region is characterised by vertical zonation among the fish assemblages. Quite distinct are successive species assemblages: in high mountainous (alpine) sections the brook trout Salmo trutta (L., 1758) (riverine forms of Salmo) is the only species. In lower mountainous sections down to the foothill zone, other rheophilous species appear in addition to the trout (species of the genera Squalius Bonaparte, 1837, Barbus Cuvier, 1816, Chondrostoma Agassiz, 1832, Alburnoides Jeitteles, 1861). Downstream, in piedmont to lowland sections, species of the genera Gobio Cuvier, 1816, Romanogobio Bănărescu, 1961 and Phoxinus Rafinesque, 1820 often predominate. The lower reaches are mostly inhabited by phytophilous species, which are typical inhabitants of slow flowing rivers and stagnant waters [1].

The recent studies conducted by us showed that the number of fish species inhabiting in rivers Debed and Aghstev and in their tributaries is not stable and is periodically being subject to changes. The latter is often 


\section{International Journal of Oceanography \& Aquaculture}

conditioned by the impact of certain factors, among which can be various hydraulic structures constructed and operating on those freshwaters. In particular, in 1990 Metsavan reservoir which is $\mathbf{1 5 8 6 . 5}$ meters high above the sea level was constructed on river Tashir up to 330 hectares.

Besides, currently 34 SHPPs operate on rivers Debed and Aghstev flowing in the territory of Armenia and on their tributaries and 7 more are being constructing. Although hydropower is considered as an important branch of renewable energy and is often viewed as an alternative, ecologically clean and environmentally friendly, a number of problems and obstacles have emerged as a result of the operation of RA SHPPs which increase the risk of SHPPs from the ecological point of view. So, being mostly constructed on small beds of rivers, the SHPP intake headquarters, from where the water of the river penetrates into pressure pipeline and flows into SHPP turbines, the riverbed is usually covered with a concrete or metal barrel. As a result, the water of small rivers stagnates and the defined volume of water environmental flow and the structure of fish ladders don't often provide the free movement of fish species and other organisms from the one side of the river to the other $[7,8]$. Besides, the absence of fish protecting nets in SHPP water intake headquarters or large cracks of current floating trash nets don't forbid the penetration of fish species inhabiting in upstream of the river especially fingerlings into the SHPPs pressure pipeline and afterwards in turbines where they are subject to mechanical and other impacts. As separate studies witness while passing through the HPPs turbines mass destruction of fish alevins and fingerlings is observed only as a result of swim bladder pressure injuries [9].

The analysis of SHPPs fish ladders types and structural solution indicated that most of the fish ladders don't meet the vital needs and physical opportunities of periodically migrating fish species of those rivers. In this sense they are mostly end in themselves and don't meet the modern requirements towards such structures. The latter is the main reason for them not to function properly.

\section{Material and the Methods}

The Ichthyological material has been collected during the period 1998-2017 - 2965 individuals of 16 fish species have been captured and studied from different areas of rivers Debed and Aghstev and their tributaries Dzoraget, Pambak, Tashir, Shnogh, Bldan, Haghartsin and Genik. While collecting and processing the material
(Selection of tools and methods of fishing, conduction of morphometric measurements, etc.) the methods of research used in Ichthyology were used [10]. The fish were caught by hand fishing nets with $45 \mathrm{~cm}$ diameter, 1.5 meter handle, $4 \mathrm{~mm}$ size net crack, fishing lift net with $70 \mathrm{~cm}$ diameter, $5 \mathrm{~mm}$ crack and fishing hooks as well as electro fishing by poachers or hand hooks. The species identification of the individuals studied was carried out according to the determinant of the fish of Armenia [11]. Afterwards the defined species were subject to morphometric measurements, their gender, maturation of sexual glands and age was determined according to the methods suggested by Pravdin [10]. When determining the number of species (numerous, common, rare) in separate reservoirs, the percentage of these species was taken from the total number of fish caught in a given reservoir or in its various areas. Conditionally "rare" was considered the taxon, the number of which in the caught fish was less than 10\%, "common" - from 10 to $30 \%$ and "numerous" - more than 30\% [4].

\section{Results and Discussion}

Currently the following fish species are found in the basin of river Debed: Salmo trutta Linnaeus, 1758, Alburnoides eichwaldii (De Filippi, 1863), Barbus lacerta De Filippi, 1865, Capoeta sevangi De Filippi, 1865, Capoeta capoeta (Güldenstädt, 1773) Alburnus filippii Kessler, 1877, Alburnus hohenackeri Kessler, 1877, Luciobarbus mursa (Güldenstädt, 1773), Romanogobio macropterus (Kamensky, 1901), Oxynoemacheilus brandtii (Kessler, 1877), Leucaspius delineatus Heckel, 1843, Abramis brama (Linnaeus, 1758), Carassius gibelio (Bloch, 1782), Pseudorasbora parva Temminck \& Schlegel, 1846, Cyprinus carpio Linnaeus, 1758, Oncorhynchus mykiss (Walbaum, 1792). Generally, currently in the basin of river Debed within Armenia 16 fish taxon are found Cyprinus carpio and Oncorhynchus mykiss of which periodically penetrate here from fish farms located along the banks of the river and its tributaries; Leucaspius delineatus, Abramis brama, Carassius gibelio и Pseudorasbora parva have penetrated here and acclimatized over the past decades [4,12-17].

According to M. Dadikyan [18] during the period 19th century of 70s 7 fish species were found in river Aghstev Salmo trutta, Salmo caspius Kessler, 1877, Capoeta capoeta, Barbus lacerta, Squalius orientalis Heckel, 1847, Alburnus filippii, Alburnoides eichwaldii. In recent years, apart from the above mentioned taxons (excluding Salmo caspius) the following fish species were discovered in river Aghstev in the territory of Armenia: Alburnus 


\section{International Journal of Oceanography \& Aquaculture}

hohenackeri, Capoeta sevangi, Luciobarbus mursa, Oxynoemacheilus brandtii, Sabanejewia aurata [19], Cobitis cf. satunini [20], Carassius gibelio, Pseudorasbora parva, Cyprinus carpio, Oncorhynchus mykiss.

So, currently the total amount of identified fish species in river Aghstev in the territory of Armenia is 16 from which Cyprinus carpio and Oncorhynchus mykiss periodically penetrate here from fish farms located on riverbeds, as for Carassius gibelio and Pseudorasbora parva are acclimatized. Moreover, taxonomic diversity of fish in river Aghstev and its tributaries differs in different parts. In upstreams, at the height of 1800-2000 meters above the sea level Brook trout is usually found. In lower streams at the height of 1000-1800 meters above the sea level Capoeta sevangi, Barbus lacerta, Alburnoides eichwaldii are found. Other species are found in much lower heights, especially not far from state border between Armenia and Azerbaijan. Such a regularity of change of vertical Ichthyofauna is observed both in uptreams and middle streams of river Kura in eastern Georgia which is conditioned by ecological characteristics of fish habitat [21]. At the same time, in river Kura flowing in the territory of Georgia and in lowlands the taxonomic fish diversity is high. So, according to Elanidze [21] in river Kura to the basin of which rivers Debed and Aghstev belong, 77 fish species are found and according to Ninua \& Japoshvili [22] - 24 fish species are found excluding climate adopted species (Table 1).

\begin{tabular}{|c|c|c|c|}
\hline $\begin{array}{c}\text { River kura, middle stream } \\
\text { from the border of georgia to } \\
\text { the mingechaur reservoir } \\
\text { (azerbaijan) [23] }\end{array}$ & $\begin{array}{l}\text { River kura in the } \\
\text { territory of georgia [21] }\end{array}$ & $\begin{array}{c}\text { River kura in the territory } \\
\text { of georgia [22] }\end{array}$ & $\begin{array}{l}\text { Basin of rivers debed and } \\
\text { aghstev (our data) }\end{array}$ \\
\hline Squalius orientalis & Squalius orientalis & Squalius orientalis & Squalius orientalis \\
\hline Chondrostoma cyri & Chondrostoma cyri & Chondrostoma cyri & - \\
\hline Romanogobio macropterus & Romanogobio macropterus & Romanogobio macropterus & Romanogobio macropterus \\
\hline Capoeta capoeta & Capoeta capoeta & Capoeta capoeta & Capoeta capoeta \\
\hline- & - & - & Capoeta sevangi \\
\hline Barbus lacerta & Barbus lacerta & Barbus lacerta & Barbus lacerta \\
\hline \begin{tabular}{|c|} 
Luciobarbus capito (Güldenstädt, \\
1773 )
\end{tabular} & Luciobarbus capito & Luciobarbus capito & - \\
\hline Alburnus filippii & Alburnus filippii & Alburnus filippii & Alburnus filippii \\
\hline Alburnus hohenackeri & Alburnus hohenackeri & Alburnus hohenackeri & Alburnus hohenackeri \\
\hline Acanthalburnus microlepis & Acanthalburnus microlepis & Acanthalburnus microlepis & - \\
\hline Alburnoides eichwaldii & Alburnoides eichwaldii & Alburnoides eichwaldii & Alburnoides eichwaldii \\
\hline Rhodeus amarus (Bloch, 1782) & - & - & - \\
\hline Cyprinus carpio & Cyprinus carpio & Cyprinus carpio & Cyprinus carpio \\
\hline Oxynoemacheilus brandtii & Oxynoemacheilus brandtii & Oxynoemacheilus brandtii & Oxynoemacheilus brandtii \\
\hline Cobitis cf. satunini & Cobitis cf. satunini & Cobitis cf. satunini & Cobitis cf. satunini \\
\hline Sabanejewia aurata & Sabanejewia aurata & Sabanejewia aurata & Sabanejewia aurata \\
\hline Silurus glanis Linnaeus, 1758 & Silurus glanis & - & - \\
\hline $\begin{array}{l}\text { Ponticola constructor } \\
\text { (Nordmann, 1840) }\end{array}$ & Ponticola constructor & Ponticola constructor & - \\
\hline- & Luciobarbus mursa & Luciobarbus mursa & Luciobarbus mursa \\
\hline- & Leuciscus aspius & Leuciscus aspius & - \\
\hline - & $\begin{array}{l}\text { Blicca bjoerkna } \\
\text { transcaucasica }\end{array}$ & $\begin{array}{l}\text { Blicca bjoerkna } \\
\text { transcaucasica }\end{array}$ & - \\
\hline - & $\begin{array}{l}\text { Alburnus chalcoides } \\
\text { (Güldenstädt, 1772) }\end{array}$ & $\begin{array}{l}\text { Alburnus chalcoides } \\
\text { (Güldenstädt, 1772) }\end{array}$ & - \\
\hline- & $\begin{array}{l}\text { Oxynoemacheilus angorae } \\
\text { (Steindachner, 1897) }\end{array}$ & $\begin{array}{l}\text { Oxynoemacheilus angorae } \\
\text { (Steindachner, 1897) }\end{array}$ & - \\
\hline
\end{tabular}




\section{International Journal of Oceanography \& Aquaculture}

\begin{tabular}{|c|c|c|c|}
\hline- & $\begin{array}{c}\text { Rutilus caspicus (Yakovlev, } \\
1870)\end{array}$ & $\begin{array}{c}\text { Rutilus caspicus (Yakovlev, } \\
1870)\end{array}$ & - \\
\hline- & Abramis brama & Abramis brama & Abramis brama \\
\hline- & Ballerus sapa (Pallas, 1814) & Ballerus sapa (Pallas, 1814) & \\
\hline- & $\begin{array}{c}\text { Sander lucioperca } \\
\text { (Linnaeus, 1758) }\end{array}$ & - & - \\
\hline- & $\begin{array}{c}\text { Perca fluviatilis } \\
\text { Linnaeus, 1758 }\end{array}$ & - & - \\
\hline- & - & Tinca tinca (Linnaeus, 1758) & - \\
\hline- & Salmo trutta & Salmo trutta & Salmo trutta \\
\hline
\end{tabular}

Table 1: Native fish of upper and middle streams of Kura River and its tributaries.

It is of vital importance to state that in river Kura, belonging to middle stream in the territory of Azerbaijan, from the border of Georgia up to Mingechaur reservoir only 17 fish species are registered. The mentioned fish species are found in river Kura and in the lower parts of its tributaries. Before the construction of Mingechaur HPP the following fish species were found in the middle streams of river Kura- Caspiomyzon wagneri (Kessler, 1870), Acipenser nudiventris Lovetsky 1828, Acipenser gueldenstaedtii Brandt \& Ratzeburg, 1833, Salmo caspius Kessler, 1877, Leuciscus aspius, Alburnus chalcoides and Ballerus sapa [23].

During the last 10 years changes in Ichthyofauna both in river Aghstev and Debed occurred. So, since $70^{\text {th }}$ of past century the fish species of Ichthyofauna of Debed and Aghstev has gone essential changes. Mainly, separate fish species such as Salmo caspius has disappeared and new species have appeared: Carassius gibelio, Cyprinus carpio, Pseudorasbora parva, Alburnus hohenackeri, Leucaspius delineatus, Oncorhynchus mykiss.

The periodical changes of the fish species in the above mentioned rivers are conditioned by the existence of different hydraulic buildings on the river streams (HPP, reservoirs, Chanels, irrigation nets, etc.) and their exploitation inadequate to environmental norms $[7,8,24]$ exploitation of numerous fish farms, poaching (including banned measures such as by electricity and toxic substances), the import of some fish species in the natural reservoirs by amateur fishers (e.g: Carassius gibelio, Cyprinus carpio, Pseudorasbora parva), pollution of mining and household waste, using waters of rivers for agricultural purposes, climate changes and by other factors.

It's worth mentioning that from those factors we have taken into consideration the SHHPs. Currently, as our studies show the significant negative impact on the biodiversity of fish species of Debed and Aghstev flowing along Armenia and their streams play the small hydro power plants.

According to our preliminary observations in small hydro power plants (SHPP) intake head structures from where the water flows into a pressure pipeline and flows into small hydro power plants (SHPP) turbines, the river stream is usually fenced by concrete or metal bulwark. As a result, small rivers' water stagnates and the defined volume of the water environmental flow and fish ladders structures don't often provide the free movement of fish species and other organisms from the one side of the river to the other side.

The analysis of small hydro power plants (SHPP) fish ladders types and structural solution indicated that most of the fish ladders don't meet the vital needs and physical opportunities of periodically migrating fish species of those rivers. In this sense they are mostly end in themselves and don't meet the modern requirements towards such structures (Figures 3-6). The latter is the main reason for them not to function properly.

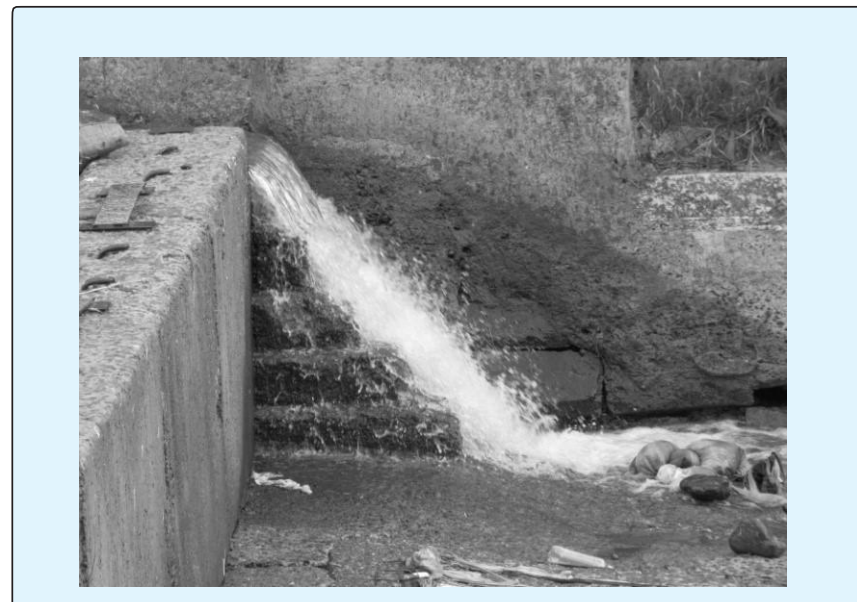

Figure 3: "Vahagni” SHPP fish ladder (r. Tandzut). 


\section{International Journal of Oceanography \& Aquaculture}
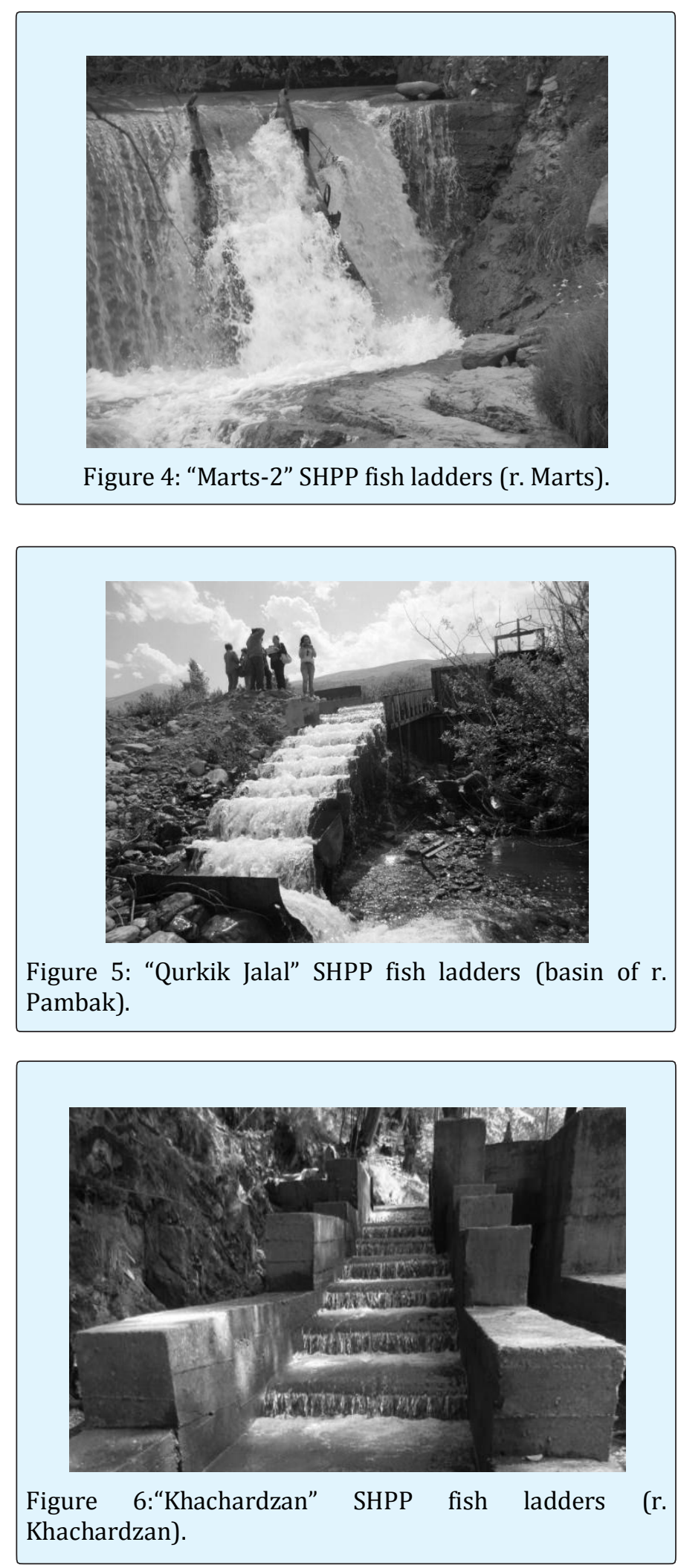

Besides, the absence of fish protecting nets in the head buildings of small hydro power plants (SHPP) intake or comparatively large cracks of floating trash nets aren't an obstacle for the appearance of fish, especially fingerlings inhabiting in upstream of the river into the small hydro power plants (SHPP) pressure pipelines and in afterwards in turbines where they are subject to various mechanical impacts. As separate studies witness fish alevins and fingerlings destruction is being noticed while passing through HPPs turbines only as a result of swim bladder pressure injuries [9].

\section{Conclusion}

The biodiversity of fish species in the Basins of Rivers Debed and Aghstev has increased twice reaching up to 19 due to the imported weed fish species which often push out the habitat fish species from their ecological niche, the resources of most of the habitat fish species especially Salmo caspius, Capoeta capoeta, Cyprinus carpio have strongly decreased, as for some migrating fish species, they are not found any more, Most of the fishes of Rivers Aghstev and Debed cannot overcome the obstacles such as concrete dams, arising as a result of small hydro power plants construction, the structures of the fish ladders don't provide their main aim, i.e. to serve as a bridge for the free movement of the fish species inhabiting different parts of the river and to ensure normal reproduction of fish resources, the absence of fish protecting nets is the reason for the loss of a large number of fingerlings and alevins.

Recommendations: (Re) construct fish ladders and fish protecting nets near reservoir dams at the small hydro power plants in accordance with the newly defined criteria, restrict the construction of small hydro power plants on the rivers that have $30 \%$ derivation or more load, review the defined dimensions of water environmental flow according to each river, review the Repubilc of Armenia legislation and the normative field for enlarging the environmental element in the usage of water resources, make the fight against poaching more effective especially against poaching with banned means, restore the damage caused to the river ecosystem and Ichthyofauna.

\section{Acknowledgements}

The authors express their gratitude to Inga Zarafyan for her support during the implementation of the work and Gohar Arakelyan for the translation of the article and for her efforts. 


\section{International Journal of Oceanography \& Aquaculture}

\section{References}

1. Naseka AM (2010) Zoogeographical freshwater divisions of the Caucasus as a part of the west asian transitional region. Proceedgs of the Zoological Institute RAS 314(4): 469-492.

2. Musayelyan MS (1989) Water Resources of the Armenian SSR. Yerevan, pp: 206.

3. Physical Geography of the Armenian (1971) Publishing house of Academy of Sciences Arm. SSR, pp: 470.

4. Pipoyan SKH (2012) Ichthyofauna of Armenia: stages of formation and current state pp: 548.

5. Mnatsakanyan BP, Tadevosyan PG (2007) Lori climate and water. Vanadzor pp: 281.

6. Nature of Armenia (2006) Armenian Encyclopedia Publisher. Yerevan pp: 685.

7. Pipoyan SKH, Arakelyan AS, Galstyan LG, Gabayan IS (2016) Fish ladders of small hydro power plants of Aghstev and Hakhum Rivers and their importance for protection of Ichtyofauna. Biological Journal of Armenia 68(1): 75-78.

8. Pipoyan SKH, Arakelyan AS, Galstyan LG, Gabayan IS (2016) Fish ladders of small hydropower plants of Debed River basin and their importance for protection of Ichtyofauna. Biological Journal of Armenia 68(2): 68-74.

9. Rare and endangered animals (1994) Fishes Reference Manual Pavlov DS, Savvaitova KA, Sokolov LI, Alekseev SS, edited by Sokolova VE. Moscow, Visshaya Shkola, pp: 334.

10. Pravdin F (1966) Guide to the fish study. Pishschevaya M, promishlenost pp: 376.

11. Pipoyan SKH, Tigranyan EA (2002) Modern Ichthyofauna of Armenia. Issues of Ichthyology 5(42): 601-604.

12. Rubenyan AR, Voskanov MV (2003) Vulnerability adaptation possibilities of Ichthyofauna and fish farm of Armenia under predicted climate changes. Armenia. Issues of climate changes. Collection of articles. Yerevan, pp: 210-216.
13. Pipoyan SKH, Tigranyan EA (1998) List of fishes of Armenian Freshwaters. Biological journal of Armenia 51(4): 258-265.

14. Arakelyan AS (2014) Modern fish species of River Debed basin and its transformation reasons. (North Armenia). Materials of $\mathrm{V}$ Russian International conference devoted to the $25^{\text {th }}$ Anniversary of AK Tembotova scientific school under RAS and 20th Anniversary of Institute of Ecology of mountainous areas after A. K. Tembotova under RAS, Nalchik, pp: 61-62.

15. Pipoyan SKH, Stepanyan IE, Arakelyan AS (2012) On the distribution Capoeta sevangi De Filippi, 1865 (Cyprinidae, Pisces) in reservoirs of Armenia (in Russian). Animal ecology, evolution and classification. Materials of International scientific practical conference, Rizan, pp: 352-353.

16. Arakelyan AS, Pipoyan SKH (2013) The fish species of Tashir River. Actual issues of Ecology and the protection of biodiversity of Russia and its surrounding countries. Materials of Russian scientific conference, Vladikavkaz, pp: 122-127.

17. Pipoyan SKH, Arakelyan AS (2015) The Disribution of Tapmouth Gudgeon Pseudorasbora parva (Temminck et Shlegel, 1846) (Actinopterygii: Cyprinidae) in Water Bodies of Armenia. Russian Journal of Biological Invasions 6(3): 179-180.

18. Dadikyan MG (1986) Fishes of Armenia. Yerevan: Academy of Sciences of the Armenian SSR, pp: 245.

19. Pipoyan SKH, Arakelyan AS, Kredzhyan TL, Stepanyan IE (2016) On discovery of the Golden spiny loach Sabanejewia aurata (De Filippi, 1863) (Cobitidae, Actinopterygii) in Aghstev River (Armenia). Biological Journal of Armenia 68(4): 61-65.

20. Pipoyan SKH, Stepanyan IE, Arakelyan AS, Kredzhyan TL, Kalashyan MY (2017) First caught of Spiny loach Cobitis sp. (Cobitidae) in Freshwaters of Armenia. Biological Journal of Armenia 2(69): 46-52.

21. Elanidze RF (1983) Ichthyofauna of rivers and lakes of Georgia. AH Georgia. SSR, Institute of Zoology, «Metsinereba», Tbilisi, pp: 320.

22. Ninua NSH, Japoshvili BO (2008) Check List Of Fishes Of Georgia. Proceedings of the Institute of Zoology XXIII Tbilisi, pp: 163-176. 


\section{International Journal of Oceanography \& Aquaculture}

23. Abdurakhmanov YA (1962) Fish species of fresh waters of Azerbaijan. SSR, Baku, pp: 407.

24. Pipoyan SKH, Arakelyan AS (2016) The impact of "Dzora HPP" on the biodiversity of fish species of
River Dzoraget and its tributaries (Northern Armenia). Ecological and evolutionary mechanisms of structural functional homeostasis of living organisms. Materials of XIV International Scientific practical ecological Conference, Belgorod, pp: 183-185. 